\title{
The Effect of Using Music Classic (Mozart) towards Student Anxiety Before The Exams
}

\author{
Risa Yuspitasari ${ }^{\left.1^{*}\right)}$, Rahmawati ${ }^{2}$, Raudah Zaimah Dalimunthe ${ }^{3}$ \\ ${ }^{1,2,3}$ Department of Guidance and Counseling, Faculty of Teacher Training and Education, \\ University of Sultan Ageng Tirtayasa, 42117 \\ *) Corresponding author: rissayp@gmail.com
}

\begin{abstract}
This research aimed to discover the level of anxiety in students before the exam and the effect of music classic (Mozart) to reduce such anxiety. The study was conducted at SMP Negeri 1 Ciruas with students with a high level of anxiety, which has been revealed from the results of the anxiety scale questionnaire using a purposive sampling technique with a total of 68 respondents. This research was used with an experimental method consisting of an experimental group and a control group. From the treatment, the results showed pre-test 12.55 in the high category and post-test 7.852 in the medium category. This shows changes in the results before and after the treatment is given. It can be concluded that the effect of the use of music (Mozart) can reduce student anxiety before the test.
\end{abstract}

Keywords: anxiety before the exam, music classic (mozart)

\begin{abstract}
Abstrak
Tujuan penelitian ini adalah untuk mengetahui tingkat kecemasan pada siswa menjelang ujian, dan mengetahui pengaruh media musik klasik (Mozart) untuk mengurangi kecemasan tersebut. Penelitian dilakukan di SMP Negeri 1 Ciruas pada siswa yang memiliki tingkat kecemasan tinggi, diungkap dari hasil angket skala kecemasan menggunakan teknik purposive sampling dengan jumlah 68 responden. Penelitian dilakukan dengan metode eksperimen, terdiri dari kelas eksperimen dan kelas kontrol. Dari treatment tersebut didapatkan hasil pre-test 12,55 dalam kategori tinggi dan post-test 7,852 dalam kategori sedang. Hal tersebut menunjukan terdapat perubahan hasil sebelum dan sesudah diberikannya treatment, maka dapat disimpulkan bahwa Pengaruh penggunaan musik (Mozart) dapat mengurangi kecemasan siswa menjelang ujian.
\end{abstract}

Kata kunci: kecemasan menjelang ujian, musik klasik (mozart) 


\section{Introduction}

Education is a basic need for improving the quality of human resources. The efforts to improvement of human resources quality. The Department of Education continues to improve the national education curriculum system. The aim of education, as stated in Act Number 20 of 2003 concerning the national education system, that education is a conscious and effort planned to create a learning atmosphere and learning process so that the students actively develop their potential. The educational process occurs when there are teaching and learning situations that will always refer to planned programs and concrete instructional goals.

Raharjayanti (2019) said, the National Examination had been carried out seventeen times, but in a long time, it turned out that the national exams had many problems and shortcomings, one of which was the problem of cheating exams which were always present every year. One of the factors of cheating is because of the lack of self-confidence so that it can cause anxiety to students.

The problem faced by students is anxiety. The anxiety faced by students is a problem that is often found in schools, for example, anxiety about one subject. The results of the study by Rizki (2018) appear that some students did not pay attention to the teacher when explaining and showed a lack of comfort when mathematics lessons took place. Out of 42 students, 25 students experienced high levels of anxiety. Anxiety occurs when learning will begin, where students start to feel worried; some students feel dizzy when working on complex math problems.

Santrock (2007), said that the National Examination was a problem directly related to schools. Many issues faced anxiety and stress caused. Students who have high levels of anxiety are the result of unrealistic parental expectations of their children's abilities. When schools provide an experience of failure (remedial) in the evaluation of examinations, student anxiety becomes more increasing.

Treatment that is used to reduce student anxiety levels is certainly very diverse. One of them, the results of a study conducted by Risyadi (2016) by applying a systematic desensitization technique, turned out to show good results, as evidenced by the decrease in average anxiety scores in students from the high anxiety category at pretest to low anxiety the post-test. The study results by Nurlaila (2011) indicate that the measurement of the pretest-posttest gain score indicates that there is a significant difference between student anxiety at the beginning of the treatment and the end of the treatment.

Several previous studies support the above statement, Suhada (Wulandari \& Rahmawati, 2014) found that self-efficacy will increase immunity to anxiety, stress, depression, and activate biochemical changes that can affect various threats. Many students feel anxious when facing exams, especially if the material submitted comes from subjects that are considered difficult; the golden age of students on the exam also arises on the results received. Barlow (Oktafianti, Wiyanti, \& Satwika, 2017) states that according to social cognitive theory, a person with a low perception of self-efficacy is implanted with potentially high levels of anxiety. This shows that self-efficacy training has a positive effect on reducing students' anxiety who will face a national final exam. Judging from the results of the study above, it can be concluded that the anxiety experienced by students is a lot of treatments that can be used to reduce anxiety, and one of which is easily applied a therapy using music. 
This therapeutic music media can be used as an approach in helping students who experience physical, behavioral, and psychological barriers so that they feel better. From the results of research conducted by Rizki (2018), there are differences in the level of mathematical anxiety between the experimental group and the control group. This study shows that Mozart's classical music method significantly influences the level of mathematics anxiety in school students with sensory characteristics. Furthermore, refers to Kurniawan (2016) The independent test results show that classical music (Mozart effect) has a positive effect on reducing the level of learning burnout in class XI students at SMA Negeri 4 Yogyakarta. Preliminary studies conducted at SMPN 1 Ciruas through guidance and counseling teachers, stated that many students experienced anxiety before the test. Look from the value of some subjects, and students have decreased, one of which is a subject that requires a lot of students to memorize various materials. In line with the anxiety questionnaire results from the two classes used in this study, the level of anxiety is generally divided into three categories. the medium category is 17 students (25\%), 13 students (19\%) high category and 38 students (68\%) low category.

The guidance and counseling teacher overcame it by using the exam grids of several subject teachers, which were then made as concise as possible so that students could easily understand the grid's contents. Then, from the test grid, the guidance and counseling teacher assigns each student to make a learning plan program from the grid to help students learn each sub in the grid. Furthermore, guidance and counseling teachers also provide positive reinforcement.

Based on the background of the above research, the researcher can determine the identification of problems regarding anxiety before the test. The existence of anxiety problems before the exam certainly can inhibit the optimization of student development, one of them in the field of learning, with the anxiety before the exam certainly can affect learning outcomes. Anxiety handlers before the exam are needed to pass each phase of the exam at the educational level. As daily tests, UTS, UKK to the UN with a maximum. Guidance and counseling teachers play the role of optimizing guidance and counseling services in schools to prevent and overcome student anxiety. Because a few researched about addresses anxiety before examining an especially junior high school student in the Serang district, the researcher will discuss and focus on the effect of the use of music classic (Mozart) on student anxiety before the exam.

\section{Methods}

\section{Participant}

The method used in this research is quantitative. This study uses a Pretestposttest control group design. In this design, stated that there were two groups chosen randomly, then were given a pre-test to find out the initial conditions between the experimental group and the control group (Sugiyono, 2012). Furthermore, after knowing the results of the two groups pre-test, the experimental class was given treatment $(\mathrm{X})$, while the control class has not given treatment $(\mathrm{X})$. After being given treatment or treatment in one of the sample groups (experimental group), they were continued with post-test administration in both classes or both groups of samples used.

Refers to Sugiyono (2012), the effect of treatment is symbolized by (O2-O1) (O4-O3) and then to see the impact of treatment based on its significance by using 
statistical tests or nonparametric statistical tests. If there is a significant difference between the experimental and control groups, then the treatment given has a significant effect. For more details about the research design used in this study, it can be seen in Table 1 as follows:

\begin{tabular}{|llll|}
\hline $\mathrm{R}$ & $\mathrm{O} 1$ & $\mathrm{X}$ & $\mathrm{O} 2$ \\
$\mathrm{R}$ & $\mathrm{O} 3$ & $\mathrm{X}$ & $\mathrm{O} 4$ \\
\hline
\end{tabular}

Figure 1 Pretest-posttest control group design

Note :

$\mathrm{R}=$ Selected group

$\mathrm{X}=$ Given the treatment used music media

$\mathrm{O} 1=$ Experimental group pre-test result

$\mathrm{O} 2=$ Experimental group post-test results

$\mathrm{O} 3=$ Control group pre-test results

$\mathrm{O} 4=$ Control group post-test results

The data collection process is carried out using a questionnaire. This research population is the students of class VIII B, F, and G, amounting to 102 students. Sampling has done by purposive sampling technique, then the sample used was 68 students. Which then narrowed down to 5 students in each class. This research began on 9 October to 8 November 2019.

\section{Measures}

The operational definition of the two variables in this study is anxiety before the test and the use of music classic (Mozart). Anxiety in facing an exam describes a subjective experience of apprehension or tension during assessment during the test, which is manifested in cognitive, affective, and physiological aspects. anxiety facing the test included in temporary anxiety (state anxiety). Student anxiety is measured using an anxiety scale consisting of cognitive, emotional, and physiological aspects. The analysis found 36 valid items and ten invalid items, where the reliable value (0.339) which then can only be used in class F and G. .. While the media of music is one of the studies as a facility for stimulating nonpharmacological relaxation that is safe, inexpensive, and effective. Music has a significant role in treating students with anxiety. The research procedure was divided into two stages 1) the Preparation stage, 2) Implementation phase, 3) the Final stage.

\section{Analysis}

Data analyzing instruments from items tested were 46 items after they were done then tested the items item validity using tools SPSS (Statistical Package for Social Science) to see the results of valid items, which is not accurately accurate and precise. Furthermore, the researcher uses a descriptive analysis of the percentage by explaining the results of the calculation of the pre-test (initial) and post-test (final evaluation) scores, which are conducted to find out the description of students' anxiety before the test using music classic (Mozart). After doing a descriptive analysis, the researcher 
continued by testing the analysis requirement by using a data normality test to detect the distribution of data in one variable to be used in the study.

Decent data to prove the research models is normal distribution data with the Kolmogorov-Smirnov formula with a significance level of 0.05 . The Wilcoxon analysis to confirm whether or not there was a change in the level of student anxiety before the test, determined the difference between pre-test and post-test. Then to find out how much effectiveness of classical music (Mozart) was used against student anxiety before the test. The amount of the contribution was also used effective linear regression, and effective regression contributions are used to see how much the contribution of independent variables to the dependent variable.

\section{Findings}

The following was a general description of eighth-grade students' anxiety before examinations at SMP Negeri 1 Ciruas obtained from the results of data collected from 68 students of VIII grade class at SMP Negeri 1 Ciruas presented in table 2.

Table 2 General description of students anxiety

\begin{tabular}{lrrr}
\hline Category & Criteria & Frequency & Percentage (\%) \\
\hline High & $\mathrm{x}>22$ & 13 & 19 \\
Medium & $13 \leq \mathrm{x} \geq 22$ & 17 & 25 \\
Low & $\mathrm{x}<13$ & 38 & 56 \\
\hline Total & & 68 & 100 \\
\hline
\end{tabular}

The result from Table 2 show that it can be seen from 68 respondents who are students of VIII class in SMP Negeri 1 Ciruas, in general, were in the medium category as many as 17 students (25\%), 13 students (19\%) was a high category and 38 students $(68 \%)$ was a low category.

Table 3 Ratio of students anxiety

\begin{tabular}{lrrr}
\hline Kind of Data & Mean & Interval (score) & Classification \\
\hline Pre-test & 12,558 & $\mathrm{X}>22$ & High \\
Posttest & 7,852 & $13 \leq X>22$ & Medium \\
\hline
\end{tabular}

Table 3 shows students' anxiety with a total population of 68 students before being treated in the high category then, after being treated using classical music (Mozart) has decreased and is in the medium category.

Table 4 Homogeneity Test

\begin{tabular}{lcccc}
\hline \multicolumn{4}{c}{ Test of Homogeneity of Variances } \\
\hline Pre-test & & & \\
Levene Statistic & df1 & df2 & Sig. \\
.094 & 1 & 8 & .767 \\
\hline
\end{tabular}

The analysis showed a significant figure higher than 0.05 , which is equal to 0.767 , which indicates that the data is homogeneous or comes from the same variant. 
Table 5 The different score before and after treatment experiment group

\begin{tabular}{|c|c|c|c|c|c|}
\hline \multirow{2}{*}{ No } & \multirow{2}{*}{ Name } & \multicolumn{2}{|c|}{ Anxiety } & \multirow{2}{*}{$\begin{array}{r}\text { Gain } \\
\text { (deviation) }\end{array}$} & \multirow{2}{*}{ Information } \\
\hline & & Pre-test & Post-test & & \\
\hline 1. & FA & 25 & 18 & 7 & Decreased \\
\hline 2. & $\mathrm{HN}$ & 24 & 9 & 15 & Decreased \\
\hline 3. & UB & 23 & 14 & 9 & Decreased \\
\hline 4. & ND & 23 & 11 & 12 & Decreased \\
\hline 5. & $\mathrm{RE}$ & 23 & 8 & 15 & Decreased \\
\hline
\end{tabular}

Control group

\begin{tabular}{|c|c|c|c|c|c|}
\hline \multirow{2}{*}{ No } & \multirow{2}{*}{ Name } & \multicolumn{2}{|c|}{ Anxiety } & \multirow{2}{*}{$\begin{array}{r}\text { Gain } \\
\text { (deviation) }\end{array}$} & \multirow{2}{*}{ Information } \\
\hline & & Pre-test & Post-test & & \\
\hline 1. & $\mathrm{PE}$ & 24 & 20 & 4 & Decreased \\
\hline 2. & $\mathrm{IMH}$ & 23 & 21 & 2 & Decreased \\
\hline 3. & AA & 23 & 15 & 8 & Decreased \\
\hline 4. & DD & 22 & 14 & 8 & Decreased \\
\hline 5. & SH & 22 & 10 & 12 & Decreased \\
\hline
\end{tabular}

From Table 5 can be seen in the different significant between pre-test and posttest results. The subject was deceased before the treatment and got a high category score, after given treatment the subject decrease in average category score. Then the researchers conducted a normality test on the experimental class based on the calculation results. The p-value on the pre-test results was 0.549 , using the level of significance $a=0.05$. If you describe the $p$-value $=0.549>0.05$, it can be concluded that it is normally distributed. For the posttest data it produces a p-value of 0.652 which pvalue $=0.652>005$. Based on these results, it can be concluded that the data obtained by researchers using both pre-test and post-test data normally distributed.

Furthermore, the control class based on the calculation results that the p-value on the pre-test results is 0.695 , using the level of significance $a=0.05$. If the translation $\mathrm{p}$-value $=0.695>0.05$, it can be concluded that the data is normally distributed. For the posttest data produces a $\mathrm{p}$-value of 0.122 which $\mathrm{p}$-value $=0.122>005$. Based on these results, it can be concluded that the data obtained by researchers, both pre-test and posttest data normally distributed data.

Based on the Wilcoxon test calculation results, the $\mathrm{Z}$ value obtained was -4.928 with a p-value (Asymp. Sig 2 tailed) of 0,000, which is less than the critical limit of research 0.05. It can be concluded that the use of classical music (Mozart) affects reducing the anxiety of students before examinations at SMP Negeri 1 Ciruas. It can be seen from the decrease in student anxiety scores before and after treatment with music (Mozart).

Furthermore, in table 8, the results of the regression analysis have a constant value of 6,517, while the value of using music classic (Mozart) is 769, so the regression equation can be written $\mathrm{Y}=6,517+\mathrm{X}=769$. If interpreted, the regression coefficient $\mathrm{X}$ value of 769 states that every $1 \%$ increase in the value of the use of music media reduces anxiety. So it can be said that the direction of the relationship of the use of music classic (Mozart) with student anxiety before the exam is positive. And the results of the calculation of effective contributions explain that the use of music classic (Mozart) contributes to reducing student anxiety before the exam by 21.0 or equivalent to $21 \%$. This shows that in addition to the use of music classic (Mozart) in anxiety students before the exam, at least $79 \%$ of other factors not examined by researchers can contribute to student anxiety before the test. 


\section{Discussion}

Anxiety is an emotion that often causes stress and is felt by many people. Sometimes anxiety is also called fear or nervous feelings. The word "anxiety" describes several phobic problems (fear of certain things or situations). Yusuf (2009) anxiety is neurotic helplessness, insecurity, immature, and the inability to deal with the guidance of reality (environment), difficulties, and stresses of daily life (Annisa \& Ifdil, 2016). Kaplan and Sadock (Yusa, 2012) also explains the negative causes that arise due to the dangers, coping, and stress that are blocking because of the onset of the sympathetic nervous system. Anxiety can occur due to unpleasant emotional experiences, continuous recovery for a long time, negatively impacting health.

Anxiety before the exams describes a subjective experience of worries or tension during the assessment of the test, manifested in cognitive, affective, and physiological aspects - anxiety before the exams included in temporary anxiety (state anxiety) (Nurlaila, 2011). Anxiety experienced by students is in line with the results of interviews with the Guidance and Counseling teacher, who said that it resulted in a decrease in grades on many subjects requiring students to memorize. Strengthened by the results of research conducted by Rudiansyah, Amirullah, and Yunus (2016), the forms of student anxiety in achieving learning outcomes is the lack of mastery of the material and lack of learning concepts.

In this situation, the students feel unpleasant emotional reactions. They are considered a threat as experienced by students when before the exams but not anxiety as a trait inherent in personality, only temporary anxiety. Efforts to overcome anxiety several efforts can have been done, such as socializing, cognitive therapy, training in positive thinking, relaxation, hypnotherapy, and music therapy. Judging from the research results at Ciruas 1 Junior High School, students experience a decrease in anxiety after receiving treatments using classical music media (Mozart).

This is in line with earlier research conducted by Hyeon-gyeong (2014), existing experimental studies evaluated the effects of music therapy on reducing anxiety through a meta-analysis. The study assessed 132 variables originating from 43 studies conducted between 2004 and 2013 and applied a random-effects model. The result, music therapy was very effective in reducing anxiety to stress.

Bernstein and Picker (Rodiyah, 2012) said that music is sounds that are organized in time and have artistic value so that they are used as a tool for expressing ideas and emotions from composers to listeners. Music can make people sad, happy, scared, restless, calm, even amused. Music does not become music if it is not heard by someone with a loud or weak volume. Mozart's music has a slow tempo, as conveyed by Jenkins, Sonata for Two Pianos in D Major is one reason Mozart has a slow character (Kurniawan, 2016). Kieran (Sakti, 2010) Music consists of several elements, namely pulse, tempo, pitch, dynamic, structure, timbre, texture, and style. The elements that cause music to make the listener experience certain changes. One important element in music is dynamic. Dynamic is a loud and weak sound. The word volume in everyday life often replaces dynamic.

According to Campbell (Melati, Suhadianto, \& Pratikno, 2018) Mozart, classical music is classical music that can stimulate the brain, especially the right hemisphere, to enhance one's thinking creativity. Many studies use Mozart's classical music as a medium to increase intelligence, reduce anxiety, improve concentration, improve memory, and develop creativity. Mozart's classical music affects slowing and balancing 
the brain, besides Mozart music that is soft and balanced between beat, rhythm, and harmony can modify brain waves. The same thing also conveyed by Djohan (Kurniawan, 2016), who quoted music can make a person from a beta condition (called) to an alpha state (meditation) while they remain conscious and awake. Music that is heard will vibrate the nerves in the brain and release emotions and feelings, such as feelings of calm, fear, happiness, or sadness.

Many studies involve music to support the learning process. The research was supported by Walberg \& Greenberg, who stated that the social environment or classroom atmosphere is the main psychological determinant that influences academic learning. Music influences teachers and students, because music can organize moods, change the mental state of students, and support the learning environment. Other research also supports the use of baroque music (Bach, Corelli, Tartini, Vivaldi, Handel, Pachebel, Mozart) and classical music (Satie, Rachmaninoff) to stimulate and maintain an optimal learning environment (Supradewi, 2010).

The need for handling to overcome the problem of anxiety can use coping skills, which are divided into two categories EFC (Emotional Focused Coping) and PFC (Problem Focused Coping. In this case, researchers use music classic (Mozart) as a way to control anxiety with the strategy PFC (Problem Focused Coping), where coping is trying to deal with stressors directly. Furthermore, Kemper and Danhauer (Saputra, 2017) mentioned one of the tools that support the success of counseling services to improve well-being, reduce stress, and distract counselees from unpleasant symptoms.

It is not easy to differentiate normal anxiety from sick anxiety because both of them were common and normal responses in daily life. Reasonable anxiety is a response to a real threat or external danger that is evident and does not originate in the presence of conflict. While anxiety sickness is a response to the existence of more complex dangers, the source of the cause is unclear and involves more conflicting souls that exist within oneself (Pranoto, 2017). Almost every individual will experience a sensation of anxiety that arises in him when responding to a situation that he considers dangerous and threatening him. If anxiety is intense and deep, so that a maladaptive situation arises, then anxiety is a symptom/symptom that disrupts an individual's emotional life.

If concluded, anxiety that often occurs in daily life is a condition that is common in every individual, because anxiety is a form of response to something. Still, sometimes the response is in the form of unrealistic fears that are felt to be disturbing or even threatening. In contrast, the anxiety is not caused by things that are detrimental to anxiety is not something to fear besides anxiety divided into two, trait anxiety and state anxiety.

\section{Conclusion and Recommendation}

\section{Conclusion}

Based on the results of the elaboration above it is concluded that anxiety that often occurs in daily life is a condition that is common in every individual because anxiety is a form of response to something. Still, sometimes the response is in the form of unrealistic fear that is felt to disturb or even threaten, while the anxiety does not cause things that are detrimental to anxiety is not something to fear. This shows that the provision of music classic (Mozart) can reduce student anxiety before the exam. 


\section{Recommendation}

Then, it is expected that parties pay more attention to the condition of students from various aspects, and provide support in facilitating teachers to take guidance and counseling training to improve the skills in providing services to all students. In addition, to the need for collaboration with all staff in the school to better understand the existence and importance of guidance and counseling services in the school. Furthermore, it can be used as reference material for further researchers to study students' anxiety before the test further.

\section{References}

Adareth, T., \& Purwoko Y. (2017). Musik klasik menurunkan tingkat stress mahasiswa yang akan menghadapi ujian. Jurnal Kedokteran Diponegoro, 6(2), 1269 1278. ISSN: 2540-8844

Annisa, D. F., \& Ifdil. (2016). Konsep kecemasan (anxiety) pada lanjut usia. Konselor, 5(2), 93-99. ISSN: 1412-9760.

Arumsari, C., Nurkamilah, M., \& Kuswita, Y. (2018). Efektifitas bimbingan kelompok untuk mendapatkan informasi kecemasan mahasiswa pendidikan teknologi informasi menghadapi ujian. Jurnal Produktif, 2(1), 30-36. ISSN: 2548-8082

Hyeon-gyeong (2014). A meta-analysis of the music therapy research to reduce stress Korean. Journal of Music Therapy, 16(1), 29-47.

Kurniawan, N. G. (2016). Efektifitas musik klasik (mozart) untuk menurunkan kejenuhan belajar siswa kelas XI SMAN 4 Yogyakarta. Jurnal Bimbingan dan Konseling, 5(7), 1-10. ISSN: 2580-6831

Melati, S. I, Suhadianto, \& Pratikto, H. (2018). Efektivitas musik mozart untuk meningkatkan kreativitas verbal. Universitas 17 Agustus 1945. Persona: Jurnal Psikologi Indonesia. 7(1), 69-78. ISSN. 2301-5985

Nurlaila, S. (2011). Pelatihan efikasi diri untuk menurunkan kecemasan pada siswasiswi yang akan menghadapi ujian akhir nasional. GUIDENA, 1(1), 1-22. DOI: http://dx.doi.org/10.24127/gdn.v1i1.348

Pranoto, H. (2017). Layanan bimbingan kelompok dalam mengurangi kecemasan peserta didik menghadapi ujian atau tes. Prosiding Seminar Nasional Pendidikan, 89-95. ISBN : 978-602-70313-2-6

Raharjayanti, Y. (2019). Dukungan sosial keluarga dan self efficacy siswa SMP dalam menghadapi ujian nasional. Jurnal Promkes: The Indonesian Journal of Health Promotion and Health Education, 7(2), 133-143. Doi: 10.20473/jpk.V7.I2.2019.133-143.

Risyadi, H. (2016). Penurunan tingkat kecemasan dalam menghadapi ujian semester melalui teknik desensitisasi sistematis pada siswa kelas X di SMAN 1 Pleret. Jurnal Riset Mahasiswa Bimbingan dan konseling, 5(2), 78-85.

Rizki, R. (2018). Perbedaan kecemasan matematika ditinjau dari pemberian musik klasik mozart. [Skripsi]. Fakultas Psikologi, Universitas Muhammadiyah Malang.

Rudiansyah, Amirullah, Yunus (2016). Upaya Guru dalam Mengatasi Kecemasan Siswa dalam Menghadapi Tes (pencapaian hasil belajar) Siswa di SMP Negeri 3 Banda Aceh. Jurnal Ilmiah Mahasiswa PPKn, 1(1), 96-109. 
Saputra, W. N. (2017). Musik dan konseling: sebuah motivasi dengan mengintegrasikan seni kreatif dalam konseling. Prosiding Seminar Bimbingan dan Konseling. ISSN: 2579-9908

Sugiyono. (2012). Metode Penelitian Pendidikan Pendekatan Kuantitatif, Kualitatif, dan $R \& D$. Bandung(ID): CV Alfabeta.

Supradewi, R. (2010). Otak, musik, dan proses belajar. Semarang. Buletin Psikologi, 18(2), 58-68. ISSN: 0854-7108

Yusa, A. (2012). Perbedaan kecemasan ditinjau dari locus of control pada warga binaan pemasyarakatan di rutan kelas 1 Surakarta. [Skripsi]. Fakultas Psikologi, Universitas Muhammadiyah Surakarta.

Yusuf, M., \& Kunto, A. (2008). Metodelogi Penelitian Kuantitatif, Kualitatif, dan Penelitian Gabungan. Jakarta(ID): Prenadamedia Group. 